\title{
Effect of Crop Load on Length, Diameter and Fruit Weight of Guava (Psidium guajava L.) cv. Allahabad Safeda at Different Stages of Fruits under Meadow Planting System
}

\author{
Prabhugouda Patil $^{*}$, A. Kiran Kumar ${ }^{2}$, A. Bhagwan ${ }^{2}$ and M. Sreedhar ${ }^{3}$ \\ ${ }^{1}$ Department of Horticulture, Fruit Science, SKLTSHU, Hyderabad-500030, India \\ ${ }^{2}$ Department of Horticulture, FRS, Sangareddy, India \\ ${ }^{3}$ Department of Genetics and Plant Breeding, Quality Control Lab, Hyderabad, India \\ *Corresponding author
}

\begin{tabular}{|c|}
\hline Keywords \\
\hline $\begin{array}{l}\text { Growth, Hasta bahar, } \\
\text { Fruit length, Days } \\
\text { After Fruit Set } \\
\text { (DAFS) and Crop load }\end{array}$ \\
\hline Article Info \\
\hline $\begin{array}{l}\text { Accepted: } \\
\text { 10 March } 2018 \\
\text { Available Online: } \\
10 \text { April } 2018\end{array}$ \\
\hline
\end{tabular}

A B S T R A C T
The study was carried out at the Fruit research station, Sangareddy, Sri Konda Laxman Telangana State Horticultural University, Hyderabad during the period of October, 2016 to February, 2017 (Hasta bahar crop) to find out the effect of crop load on growth attributes of guava (Psidium guajava L.) cv. Allahabad Safeda under meadow planting system. The treatments of the experiment were crop load levels i.e. retaining of 5, 10, 15, 20 fruits per plant and control (No thinning) and second factor as a observations recorded after fruit thinning i.e. (1) 30 days after fruit set (2) 60 days after fruit set (3) 90 days after fruit set and (4) at the time of harvest for to study the growth and development of fruits with crop load levels. The ages of the plants were 4-5 years. The experiment revealed that the significant differences were noticed in guava cv. Allahabad Safeda for fruit growth parameters studied in hasta bahar crop. Fruit length, fruit diameter and fruit weight of guava fruits increased continuously from the initial stage of fruit development till maturity and up to harvest. The increases in fruit weight and diameter were comparatively more between 90 to at the time of harvest and 60 to 90 days after fruit set than 30 to 60 days after fruit set where the increase in fruit weight and diameter was slow. The difference of fruit growth and development was shown after 30 days after fruit set. The crop load of 5 fruits per plant recorded highest fruit length $(7.34 \mathrm{~cm})$, fruit diameter $(4.46 \mathrm{~cm})$ and fruit weight $(236.46 \mathrm{~g})$ at the time of harvest followed by 10 fruits per plant and lower fruit length $(3.43 \mathrm{~cm})$, fruit diameter $(3.48 \mathrm{~cm})$ and fruit weight $(40.07)$ at the time of harvest in control (no thinning).

\section{Introduction}

Guava (Psidium guajava L.) is one of the most important fruit of Tropical and Sub Tropical region of India. It was originated in Tropical America. Commercially cultivated in Cuba, Malaysia, Mayanmar, Hawaiian Island,
Venezuela, Australia, S Africa, Bangladesh, Brazil, Colombia, Cameroon, Mexico, Peru, Thailand, Sudan, Kenya and India. Fourth largest fruit (after Mango, Banana, Citrus) grown in India and UP, Bihar, MP, Maharastra, WB, Thripura. UP is the most important state for producing Guava. 
Allahabad-Varanasi region has the reputation for producing the best quality guava in the country as well as in the world. Guava fruit is known for its "vitamin-C", minerals like calcium, iron and phosphorous with pleasant aroma and flavor (Dhaliwal and Dhillon, 2003) and its better adoptability eulogized it as "the apple of tropics". Guava bears on current season's growth and flowers appear in the axils of new leaves therefore it responds well to pruning (Kumar and Rattanpal, 2010).

The increasing importance of guava as a commercial tropical fruit crop, both for table purposes and processing, demands its wide spread cultivation ensuring regular cropping and higher production.

Generally, guava is cultivated using traditional planting system $(6.0 \times 6.0 \mathrm{~m})$, under which it is difficult to achieve desired levels of production, because large trees provide low production per unit area and need high labour inputs. Moreover, large trees take several years before they come into bearing and overall cost of production per unit area is further increased. Hence, there is overriding need to improve the existing planting system.

There is currently a worldwide trend to plant fruit trees on permanent high-density planting $(3 \times 1.5 \mathrm{~m})$ or meadow orchard $(2.0 \times 1.0 \mathrm{~m})$ and to manipulate tree growth using canopy management to control tree growth patterns and tree shape and maintaining high fruit production of desired size and quality (Gorakh Singh, 2010).

A package of practice is imperative to enhance the growth of fruits by crop load and fruit thinning in hasta bahar season, hence in this line the research has been conducted with objective of the study the crop load effects on growth and development of guava at different fruit developmental stages.

\section{Pattern of growth and development of guava fruits}

The pattern of growth as represented by length and diameter and weight followed "Double sigmoid curve" and could be differentiated into three distinct phases. The first growing phase corresponds to an accelerated growth, beginning a few days after anthesis and goes on for 45 or 60 days during the rainy season or winter and during spring, respectively. The second one is relatively slow and last about 30 days, except during spring when it extends up to 60 days; seed ripening and hardening occur at this growing phase. In the third one it is observed an exponential increase of fruit growing rate resulting in increased fruit diameter and length; this period last for 30, 60 and 90 days in raining season, winter and spring respectively. Fruit length, diameter and weight increased gradually from fruit set to harvest (Rathore, 1976). The presence or absence of fruit on guava trees has a major effect on their photosynthetic performance and growth (Flore and Lakso, 1989; Forshey and Elfving, 1989; Byers, 2003 and Wunsche and Ferguson, 2005). Effects of time and severity of flower or fruit thinning or crop load adjustment, and concomitant alteration of fruit: leaf ratios, tree and fruit physiology have been extensively studied to determine their effects on fruit size, yield and quality at harvest. The rate of fruit growth depends primary on crop load (Palmer et al., 1997). A low crop load resulted in a larger growth rate than a high crop load, due to there being less competition for available photo-assimilates. If the demand for photo-assimilates exceeded the amount available early in the season, due to a heavy crop load, this leads to decreased fruit growth (Lakso and Corelli Grappadelli, 1993). The effects of crop load on fruit growth and on final fruit weight are well-documented (Forshey and Elfing, 1989; Palmer et al., 1997). Fruit weight at harvest was negatively correlated with crop load, and fruit weight was 
greatest when there was minimum competition between fruit (Palmer et al., 1997).

\section{Materials and Methods}

The experiment was carried out during the period of October, 2016 to February, 2017 (Hasta bahar crop) at Fruit Research Station (FRS), Sangareddy, SKLTSHU, Telangana. Fruit Research Station was situated at an altitude of 1743 feet above mean sea level on $17^{\circ} 37.300^{\prime}$ North latitude and $78^{\circ} 04.601^{\prime} 18$ East longitude. The experiment was laid out in randomized block design with factorial concept with 20 treatments in 3 replications. The fruits were tagged in four directions of plant during the thinning time at initial stage of fruit growth as per the treatments; plants are of 4-5 years old and planted in $2 \times 1 \mathrm{~m}$ spacing. The data was recorded at monthly intervals from fruit set to harvest to observe the fruit development pattern with crop load effects. The treatments of the experiment were crop load levels i.e. retaining of 5, 10, 15, 20 fruits per plant and control (No thinning) and second factor as a observations recorded after fruit thinning i.e. (i) 30 days after fruit set (ii) 60 days after fruit set (iii) 90 days after fruit set and at the time of harvest.

In these treatments, total number of fruits per plant in each replication was counted after fruit set. Out of these 5, 10, 15, 20 fruits per plant of fruits were retained and remaining fruits were thinned randomly by manual thinning and in control (no thinning), the second factor is considered as a treatment for knowing of crop load effects at different stages of fruit growth.

\section{Results and Discussion}

\section{Fruit length (cm)}

The fruit length varied significantly after thinning at 30,60, 90 days after fruit set and at the time of harvest of guava during study.
Gradual increase in fruit length was observed during fruit growth from fruit set to time of harvest. The fruit length varied significantly during study. The average fruit length at 30 days after fruit set $(2.21 \mathrm{~cm})$ followed by 60 days after fruit set $(2.96 \mathrm{~cm}), 90$ days after fruit set $(4.58 \mathrm{~cm})$ and significantly maximum fruit length was noticed at the time of harvest $(6.34 \mathrm{~cm})$. These results are evident from Singh and Jain (2007) the fruit growth of Allahabad Safeda in terms of length and width was maximal during 30-60 days. Man Bihari and Suryanarayan (2011) also observed the variation among fourteen genotypes studied in respect to fruit length in guava. Patel et al., (2015) noted that a gradual increase in fruit length was observed in different genotypes of guava throughout development and ripening stage of the fruits. The data regarding the fruit length of guava cv. Allahabad Safeda significantly varied among the treatments (5, 10, 15, 20 fruits per plant and control (no thinning)). The maximum fruit length was marked in 5 fruits per plant $(4.65 \mathrm{~cm})$ followed by 10 fruits per plant and minimum fruit length was noticed in control $(3.43 \mathrm{~cm})$ (Table 1 and Fig. 1).

The increase in fruit length and breadth might be due to the reduction in the number of fruits per plant thereby increasing the size of the cell and cell elongation which resulted in maximum accumulation of the food materials in the developing fruits, thus improving the fruit size. These results are in collaboration with the findings of Arora and Chanana (2001) and Casierra et al., (2007). The interaction of days after fruit set and crop load shown significant variation. The interaction of days after fruit set and crop load shown significant variation (Table 3 ). The highest fruit length was observed in combination of 5 fruits per plant $(7.34 \mathrm{~cm})$ and followed by 10 fruits per plant $(6.50 \mathrm{~cm})$ and minimum fruit length was noticed in control $(5.29 \mathrm{~cm})$ at the time of harvest (Fig. 4). 
Table.1 Effect of crop load on fruit length $(\mathrm{cm})$ at 30, 60, 90 days after fruit set and at the time of harvest in guava cv. Allahabad Safeda under meadow planting system

\begin{tabular}{|c|c|c|c|c|c|c|}
\hline Treatments & \multicolumn{4}{|c|}{ Days after fruit set (DAFS) } & \\
\hline Crop load $(\mathbf{C L})$ & $\mathbf{3 0}$ & $\mathbf{6 0}$ & $\mathbf{9 0}$ & At harvest & Mean \\
\hline 5 fruits per plant & 2.62 & 3.68 & 4.96 & 7.34 & $4.65^{\mathrm{e}}$ \\
\hline 10 fruits per plant & 2.40 & 3.31 & 4.70 & 6.50 & $4.23^{\mathrm{d}}$ \\
\hline 15 fruits per plant & 2.18 & 2.83 & 4.62 & 6.40 & $4.00^{\mathrm{c}}$ \\
\hline 20 fruits per plant & 2.01 & 2.63 & 4.40 & 6.20 & $3.81^{\mathrm{b}}$ \\
\hline Control & 1.87 & 2.36 & 4.21 & 5.29 & $3.43^{\mathrm{a}}$ \\
\hline Mean & $2.21^{\mathrm{A}}$ & $2.96^{\mathrm{B}}$ & $4.58^{\mathrm{C}}$ & $6.34^{\mathrm{D}}$ & \\
\hline & DAFS(A) & $\mathbf{C L} \mathbf{( B )}$ & & $\mathbf{A} \times \mathbf{B}$ & \\
\hline CD at 5\% & 0.14 & 0.16 & & 0.31 & \\
\hline SE $\mathbf{( m )} \pm$ & 0.05 & 0.06 & & 0.11 & \\
\hline
\end{tabular}

Table.2 Effect of crop load on fruit diameter (cm) at 30, 60, 90 days after fruit set and at the time of harvest in guava cv. Allahabad Safeda under meadow planting system

\begin{tabular}{|c|c|c|c|c|c|c|}
\hline Treatments & \multicolumn{5}{|c|}{ Days after fruit set (DAFS) } \\
\hline Crop load (CL) & $\mathbf{3 0}$ & $\mathbf{6 0}$ & $\mathbf{9 0}$ & At harvest & Mean \\
\hline 5 fruits per plant & 1.74 & 3.78 & 4.97 & 7.37 & $4.46^{\mathrm{d}}$ \\
\hline 10 fruits per plant & 1.43 & 3.05 & 4.89 & 7.15 & $4.13^{\mathrm{c}}$ \\
\hline 15 fruits per plant & 1.68 & 3.07 & 4.70 & 7.04 & $4.12^{\mathrm{c}}$ \\
\hline 20 fruits per plant & 1.59 & 2.45 & 4.42 & 6.58 & $3.76^{\mathrm{b}}$ \\
\hline Control & 1.69 & 2.27 & 3.53 & 6.44 & $3.48^{\mathrm{a}}$ \\
\hline Mean & $1.63^{\mathrm{A}}$ & $2.92^{\mathrm{B}}$ & $4.50^{\mathrm{C}}$ & $6.92^{\mathrm{D}}$ & \\
\hline & DAFS(A) & $\mathbf{C L} \mathbf{( B )}$ & & $\mathbf{A} \times \mathbf{B}$ & \\
\hline CD at 5\% & 0.17 & 0.19 & & & 0.37 & \\
\hline SE $\mathbf{( m )} \pm$ & 0.06 & 0.07 & & 0.13 & \\
\hline
\end{tabular}

Table.3 Effect of crop load on fruit weight (cm) at 30, 60, 90 days after fruit set and at the time of harvest in guava cv. Allahabad Safeda under meadow planting system

\begin{tabular}{|c|c|c|c|c|c|}
\hline Treatments & \multicolumn{3}{|c|}{ Days after fruit set (DAFS) } & \\
\hline Crop load (CL) & $\mathbf{3 0}$ & $\mathbf{6 0}$ & $\mathbf{9 0}$ & At harvest & Mean \\
\hline 5 fruits per plant & 3.99 & 31.04 & 73.53 & 236.46 & $86.25^{\mathrm{e}}$ \\
\hline 10 fruits per plant & 3.93 & 20.25 & 71.19 & 198.31 & $73.42^{\mathrm{d}}$ \\
\hline 15 fruits per plant & 3.54 & 18.77 & 66.98 & 181.63 & $67.73^{\mathrm{c}}$ \\
\hline 20 fruits per plant & 3.43 & 16.81 & 56.94 & 161.01 & $59.54^{\mathrm{b}}$ \\
\hline Control & 3.50 & 15.30 & 41.85 & 99.62 & $40.07^{\mathrm{a}}$ \\
\hline Mean & $3.68^{\mathrm{A}}$ & $20.43^{\mathrm{B}}$ & $62.09^{\mathrm{C}}$ & $175.40^{\mathrm{D}}$ & \\
\hline & DAFS(A) & $\mathbf{C L}(\mathbf{B})$ & & $\mathbf{A} \times \mathbf{B}$ & \\
\hline CD at 5\% & 2.77 & 3.10 & & 6.19 & \\
\hline SE $\mathbf{( m )} \pm$ & 0.97 & 1.08 & & 2.16 & \\
\hline
\end{tabular}


Fig.1 Effect of crop load on fruit length (cm) at 30, 60, 90 days after fruit set and at the time of harvest in guava cv. Allahabad Safeda under meadow planting system

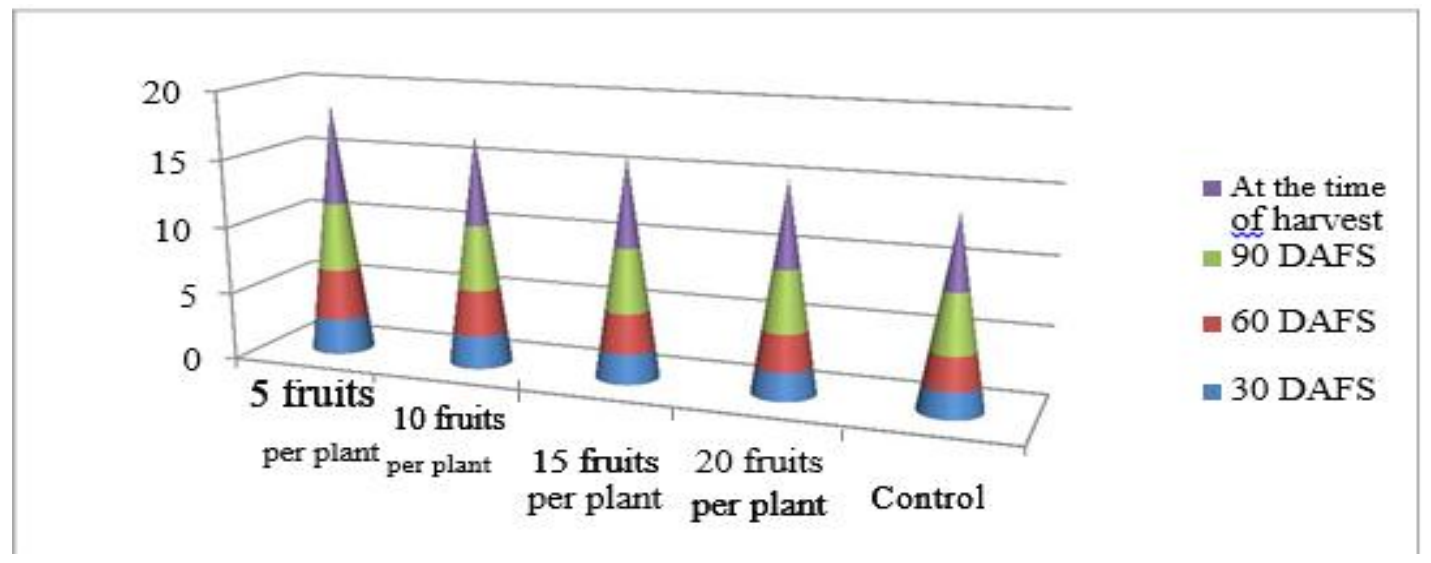

Fig.2 Effect of crop load on fruit weight (gm) at 30, 60, 90 days after fruit set and at the time of harvest in guava cv. Allahabad Safeda under meadow planting system

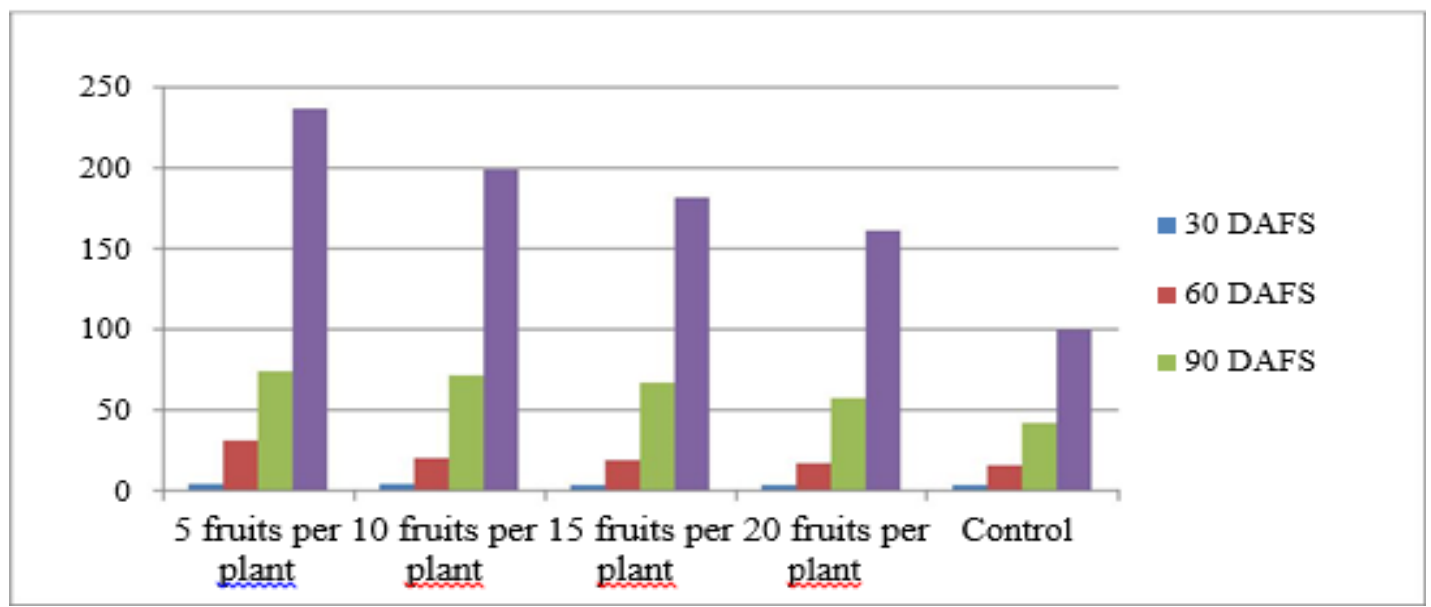

Fig.3 Effect of crop load on fruit diameter (cm) at 30, 60, 90 days after fruit set and at the time of harvest in guava cv. Allahabad Safeda under meadow planting system

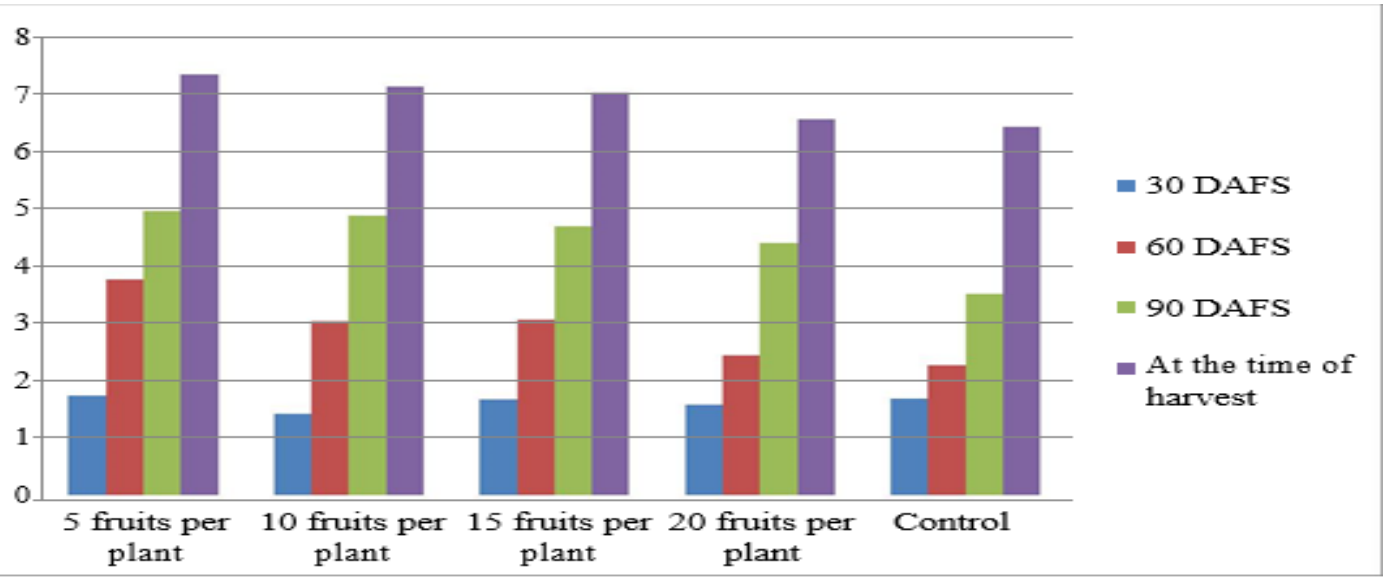


Fig.4 Variation in the fruits size at the time of harvest with crop loads i.e. 5, 10, 15, 20 fruits per plant and control

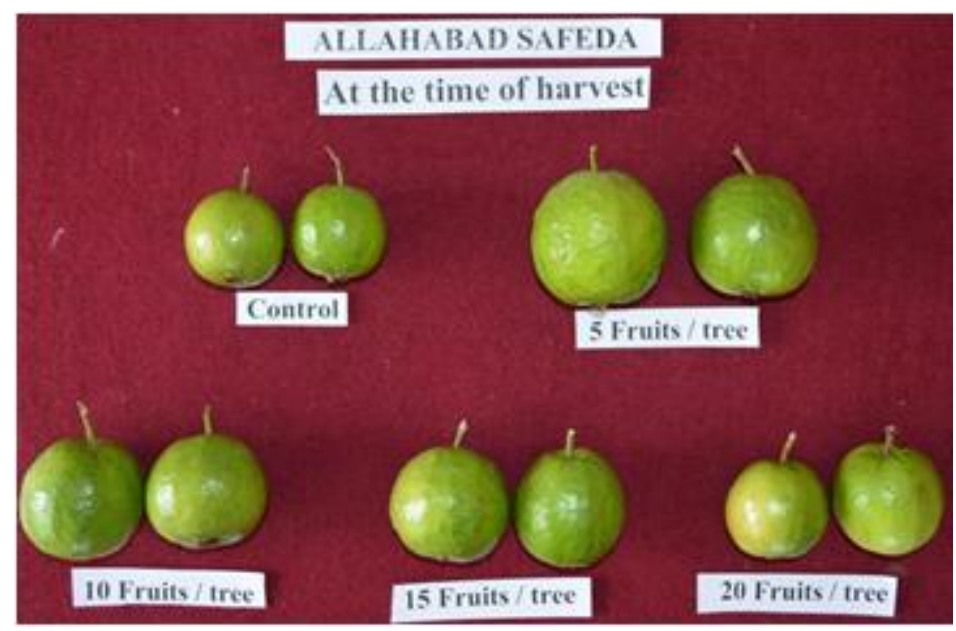

\section{Fruit diameter $(\mathrm{cm})$}

The fruit diameter of guava recorded a cumulative development from initial stage of fruit growth till maturity and at the time of harvest. The average diameter of fruits was $(1.63 \mathrm{~cm})$ on 30 days after fruit set followed by 60 days after fruit set $(2.62 \mathrm{~cm}), 90$ days after fruit set $(4.50 \mathrm{~cm})$ and significantly maximum fruit diameter $(6.92 \mathrm{~cm})$ was noticed at the time of harvest (Fig. 3). The increase in fruit diameter was comparatively more between 30 to 60 days after fruit set and 90 days to at the time of harvest than 60 to 90 days after fruit set where the accumulative was slow. The major increasing fruit growth could be attributed to the increasing cell size where as slow growth in between 60 to 90 days after fruit set was perhaps due to faster development of seed during this period that attributed to slow growth of the pulp (Dhillon et al., 1987 and Mercado Silva et al., 1998) in guava. The collective data revealed that significant variation was noticed in fruit load (5, 10, 15, 20 fruits per plant and control). However, the highest fruit diameter was noted with 5 fruits per plant $(4.46 \mathrm{~cm})$ followed by 10 fruits per plant which is on par with 15 fruits per plant as compared to control (3.48 $\mathrm{cm})$. Due to reduction in crop load reduces initial competition for carbohydrates; thereby improving the distribution of assimilates between fruit, producing fruit with greater mass and diameter (Byers et al., 2003). The interaction of days after fruit set and crop load shown significant variation (Table 2). At the time of harvest recorded maximum fruit diameter in 5 fruits per plant $(7.37 \mathrm{~cm})$ which is followed by 10 fruits per plant $(4.97 \mathrm{~cm})$ at 90 days after fruit set and minimum is at initial stage of fruit growth i.e. 30 days after fruit set with 10 fruits per plant $(1.43 \mathrm{~cm})$.

\section{Fruit weight}

A significant variation in fruit weight of guava cv. Allahabad Safeda was observed at various stages of fruit development $(30,60$, 90 days after fruit set and at the time of harvest). The data presented in (Table 3) showed an increasing trend in fruit weight from initial stage of fruit growth till up to harvest (Fig. 2). The weight of the fruits was increased from 30 days after fruit set $(3.68 \mathrm{~g})$ followed by 60 days after fruit set $(20.43 \mathrm{~g})$, 90 days after fruit set $(62.09 \mathrm{~g})$ and reached the maximum of $(175.40 \mathrm{~g})$ on at the time of harvest. Similar finding was also reported by Dhillon et al., (1987) they found that fruit weight in Allahabad Safeda and Sardar 
increased up to 130 and 120 days, respectively, in the rainy season and up to 140 and 130 days, respectively in the winter season. The slow growth during 60 to 90 DAFS might be due to rapid development of seed resulting in slow growth of the pulp.

The increase in fruit weight could be attributed to an increase in the size of the cells and accumulation of food substances in the intercellular spaces in fruit (Bollard, 1970). The data regarding the fruit weight of guava cv. Allahabad Safeda significantly affected by crop load. The (Table 3) indicates that the maximum fruit weight was noticed in 5 fruits per plant $(86.25 \mathrm{~g})$ followed by 10 fruits per plant $(73.42 \mathrm{~g})$ and minimum fruit weight was noticed in control (40.07 g). Because of number of fruits per plant there by increasing the availability of photosynthates and lesser nutritional competition among the developing fruits, thus improving the fruit weight (Kousar et al., 2016) these results get support from Casierra et al., (2007).

As crop load increased fruit weight showed decreasing trend. More nutrients were available to the fruits as competition among fruits was less. This may have induced an increase in cell division. These factors lead to an increase in fruit size and weight. These results are in agreement with the findings of Embree et al., (2007). There is significant difference among the crop load at the time of harvest with 5 fruits per plant having highest weight of fruits (236.46 g) which is followed 90 days after fruit set $(73.53 \mathrm{gm})$ and there is lowest at 30 days after fruit set with 20 fruits per plant $(3.43 \mathrm{~g})$.

From the results, it can be concluded that thinning of fruits (i.e. retaining of 5, 10, 15 and 20 fruits per plant) significantly improved the fruit growth parameters i.e. fruit length, fruit diameter and fruit weight. Hence there is a scope for distribution of crop load in two seasons instead of one season will reduce stress on the plants and income of farmers can also be increased due to availability of fruits in mrig bahar and hasta bahar.

\section{References}

Arora, N. K. and Chanana, Y. R. 2001. Effect of hand thinning of maturity, yield, and quality of Peach (Prunus persica Batsch.) cv. Flordaprince. Journal of Research Punjab Agricultural University. 38:168-172.

Bollard, E. G. 1970. The physiology and nutrition of developing fruits. In: A.C. Hulme (Ed.) "The biochemistry of fruits and their products". International Academic Press, London. 387-425.

Byers, R. E. 2003. Flowering and fruit thinning and vegetative: fruiting balance. In Apples: Botany, Production and Uses. Eds. D.C. Ferree and I.J. Warrington. CABI Publishers, Cambridge, MA. 409 - 436.

Casierra, P. F., Rodriguez, P. J. I., Cardenas and Hernandez, J. 2007. Leaf to fruit ratio affects yield, fruit growth and fruit quality of peach (Prunus persica Batsch, cv. Rubidoux). Revista Facultad Nacional de Agronomia Medellin. 60: 3657-3669.

Dhaliwal, G. S. and Dhillon, S. K. 2003. Effect of tree size on physicochemical characteristics of fruits of guava cv. Sardar. Indian Journal Horticulture. 60: 312-317.

Dhillon, B. S., Singh S. N., Kundal, G. S., Minhas, P. P. S. 1987. Studies on the developmental physiology of guava fruit (Psidium guajava L.) II. Biochemical characters. Punjab Horticulture Journal. 27: 212- 221.

Embree, C. G., Myra, M. T. D., Nichols, D. S. and Wright, A. H. 2007. Effect of blossom density and crop load on growth, fruit quality, and return bloom 
in „Honeycrisp" apple. Horticultural Science. 42:1622-1625.

Flore, J. A. and Lakso, A. N. 1989. Environmental and physiological regulation of photosynthesis in fruit crops. Horticulture Reviews. 11: 111157.

Forshey, C. G. and Elfving, D. C. 1989. The relationship between vegetative growth and fruiting in apple trees. Horticulture Reviews. 11: $229-287$.

Gorakh Singh. 2010. Development of meadow orchard in Guava for higher production. Progressive Horticulture. Vol. 42(2): 129-133.

Kousar Javaid, K. R., Dar, S. N., Qureshi, M. S. W., Rahila Shameem, R. H. S. Raja, S. N. Kirmani and Y. A. Basu. 2016. Influence of crop load and foliar nutrient sprays on growth, yield and quality of apple (Malus $\times$ Domestica Borkh.) Cv. Red Delicious. Thebioscan. 11(2): 1187-1191.

Kumar, Y. and Rattanpal, H. S. 2010. Effect of pruning in guava planted at different spacings under punjab conditions. Indian Journal of Horticulture 67: 115119.

Lakso, A. N. and Corelli Grappadelli, L. (1993). Implications of pruning and training practices to carbon partitioning and fruit development in apple. Acta Horticulturae, 332, 231-240.

Man Bihari and Suryanarayan. 2011. Genetic diversity, heritability, genetic advance and correlation coefficient in guava
(Psidium guajava). Indian Journal of Agricultural Sciences. 81: 107-110.

Mercado-Silva, Benito Bautista EP M de los A, Garcia Velasco.1998. Fruit development, harvest index and ripening changes of guavas produced in central Mexico. Postharvest Bio and Tech. 13: 143-150.

Palmer, J. W., Giuliani, R. and Adams, H. M. (1997). Effects on crop load on fruit and leaf phosynthesis of Braeburn/M26 apple trees. Tree Physiology, 17, 741746.

Patel, R. K., Maiti, C. S., Deka, B. C., Deshmukh, N. A., Verma, V.K. and Nath, A. 2015. Physical and biochemical changes in guava (Psidium guajava L.) during various stages of fruit growth and development. International Journal of Agriculture, Environment and Biotechnology. 8(1): 75-80.

Rathore, D. S. 1976. Effect of season on the growth and chemical composition of guava (Psidium guajava L.) fruits. Journal Horticulture Science. 51(1): 4147.

Singh, P. and Jain, V. (2007). Fruit growth attributes of guava (Psidium guajava L.) cv. Allahabad Safeda under agroclimatic conditions of Chhattisgarh. Acta hortic.735, 335-338.

Wünsche, J. N. and Ferguson, I. B. 2005. Crop load interactions in apple. Horticulture Reviews. 31:231-290.

\section{How to cite this article:}

Prabhugouda Patil, A. Kiran Kumar, A. Bhagwan and Sreedhar, M. 2018. Effect of Crop Load on Length, Diameter and Fruit Weight of Guava (Psidium guajava L.) cv. Allahabad Safeda at Different Stages of Fruits under Meadow Planting System. Int.J.Curr.Microbiol.App.Sci. 7(04): 1336-1343. doi: https://doi.org/10.20546/ijcmas.2018.704.149 